Article

\title{
The World Bank and Healthcare Reforms: A Cross-National Analysis of Policy Prescriptions in South America
}

\author{
Gabriela de Carvalho \\ Collaborative Research Centre 1342, University of Bremen, Germany; decarvalho@uni-bremen.de
}

Submitted: 31 July 2021 | Accepted: 28 September 2021 | Published: 25 January 2022

\begin{abstract}
Recent literature on comparative welfare states has recognised the central role international financial institutions (IFIs) play in shaping social policy. Particularly in low- and middle-income countries (LMICs), where constraints often lead to reliance on foreign resources, IFIs can act as agenda-setters, transferring their ideas to vulnerable governments. The neoliberal model promoted by IFIs at the end of the 20th century reveals their influence on domestic policy in South America. This study analyses the impact of World Bank (WB) prescriptions on healthcare reform legislation in five South American countries: Argentina, Bolivia, Colombia, Paraguay, and Peru. In doing so, it attempts to answer the following questions: Are LMICs receptive to IFIs' healthcare system prescriptions? More precisely, have WB policy prescriptions been adopted in healthcare reform legislation in South American countries? If so, in what way? Through content analysis, this study examines domestic healthcare legislation vis-à-vis the WB's prescriptions. The main findings show that countries are receptive to IFIs prescriptions, making them a legitimate source of policy recommendations. Further, the results suggest a correlation between economic development and reliance on foreign resources and the degree to which countries adhere to IFIs prescriptions.
\end{abstract}

\section{Keywords}

healthcare legislation; healthcare reform; international financial institutions; low- and middle-income countries; neoliberal health model; policy transfer; social policy prescriptions; South America; World Bank

\section{Issue}

This article is part of the issue "Recent Trends in Inequality and Exclusion in Latin America" edited by Maria Amparo Cruz Saco (Connecticut College / Universidad del Pacífico).

(C) 2022 by the author(s); licensee Cogitatio (Lisbon, Portugal). This article is licensed under a Creative Commons Attribution 4.0 International License (CC BY).

\section{Introduction}

At the centre of recent comparative literature on the welfare state is the role of international financial institutions (IFIs) in shaping domestic policymaking. Further, policy transfer and diffusion research suggests the mechanisms through which ideas migrate to countries from foreign sources. Emulation and learning processes indicate that countries may conform to international trends without assessing their content or adapt foreign knowledge to fit their own circumstances. Especially for lowand middle-income countries (LMICs), which can substantially rely on foreign resources, IFIs can use their prominence to influence countries to adopt specific agendas (Clements et al., 2013; Kaasch, 2013). For example, with the neoliberal health model's dissemination in the last decades of the 20th century, the World Bank (WB) was considered a main healthcare reform advocate. Extant research has addressed the policy implications and outcomes of such reform adjustments (e.g., Haggard \& Kaufman, 2008; Homedes \& Ugalde, 2005). However, the influence of prescriptions on domestic healthcare legislation has received less attention, especially in cross-national studies. This is of interest because analysis of the legal basis of healthcare systems displays variations among countries, demonstrates how countries interact with IFIs, and offers potential explanations regarding why nation-states approach IFIs prescriptions differently. Furthermore, if legislation is fully implemented, adopting foreign ideas may have direct implications for healthcare access and, consequently, health outcomes. 
This research examined how IFIs policy agendas, specifically that of the WB, were adopted in domestic legislation in South American LMICs and addressed the following questions: Are LMICs receptive to IFIs' healthcare system prescriptions? Have WB policy prescriptions been adopted in healthcare reform legislation in South America? If so, in what way? To answer these questions, a content analysis was conducted of key domestic healthcare reform legislation in Argentina, Bolivia, Colombia, Paraguay, and Peru, vis-à-vis the prescriptions set by the WB's World Development Report: Investing in Health (1993). This approach allows for the comparison of reforms in countries with distinct domestic conditions but similar international economic and ideological contexts within a specific timeframe, when a uniform neoliberal agenda was proposed to address the consequences of economic crises in the region. The main findings of this research show that countries were receptive to IFIs prescriptions, making them a legitimate source of policy recommendations. Further, it suggests a correlation between economic development and reliance on external resources and the degree to which countries adhered to WB prescriptions.

This study, however, is not without limitations. First, only legislation from reforms in the 1990s was analysed, without considering previous healthcare systems. The measures presented in the examined legislation could have replicated what was already in place. Second, the study did not consider healthcare system performance before and after the reforms, which may suggest the willingness to accept foreign models and outcomes of such recommendations. Third, this study only analysed the adoption of IFIs prescriptions based on the language of domestic legislation, without considering whether these were actually implemented or impacted healthcare systems beyond their legal framework. Finally, although economic and political factors in the year prior to the reform were presented, internal conditions were not analysed in detail.

First, this article discusses IFIs' influence in shaping social policy, the mechanisms through which prescriptions were conveyed from these organisations to countries, and the roles of the WB and neoliberal health agenda in setting healthcare policy. Then, healthcare reform in five South American countries is described, followed by a discussion on the methods used to analyse healthcare reform legislation. Finally, the analysis results are examined, and the findings are used to evaluate how WB policy prescriptions were translated into domestic healthcare legislation.

\section{The Influence of International Financial Institutions on Domestic Policy}

New approaches to social policy, such as global social policy and the transnational interdependence framework, emphasise IFIs' role in shaping policy and related processes (Deacon, 2007; Kaasch, 2013; Obinger et al., 2012).
Beyond operating as financing agents through loans and aid, IFIs provide models and prescriptions, champion regulation and rights, and facilitate policy exchange (Kaasch, 2013; Orenstein, 2008). Research suggests that the influence of IFIs is greater in LMICs, as these institutions have high power status, leaving governments of less advanced economies more willing to accept their prescriptions. Especially during crises, IFIs can exert their will on LMIC governments, acting as agenda-setters of domestic reform (Stallings, 1992; Wireko \& Béland, 2017). For instance, research indicates that the WB substantially impacted the wave of structural reforms in Latin America at the end of the 20th century, spreading beliefs regarding the economic gains of privatisation and using financial and technical resources to persuade policymakers (Haggard \& Kaufman, 2008; Madrid, 2005).

IFls can influence domestic social policy by providing ideas and practical models that promote normative conceptions regarding desirable forms of social policy (i.e., prescriptions; see Deacon, 2007). Research suggests that these foreign ideas indicate the range of possible policy solutions and suggest the associated costs and benefits of adopting them (Madrid, 2005). As these propositions are not legally bound, countries have autonomy to accept or reject ideas IFIs disseminate. However, asymmetrical power relations between IFIs and nationstates can affect willingness to adopt recommendations (Wireko \& Béland, 2017). According to Simmons et al. (2008), international ideas are transferred/diffused and institutionally embedded through competition, coercion, learning, and emulation mechanisms. Competition occurs when governments adopt policies to gain a competitive advantage over countries competing for the same resources (Obinger et al., 2012). Coercion suggests that prominent actors use their power to influence LMIC policymaking, leaving governments unable to seek alternatives to IFIs agendas (Simmons et al., 2008; Wireko \& Béland, 2017).

Although studies have highlighted the importance of the previously mentioned mechanisms for policy diffusion/transfer (e.g., Leibfried \& Pierson, 1995; Obinger et al., 2012), the present analysis focused on learning and emulation, to determine whether domestic legislation can demonstrate how IFIs prescriptions are incorporated into laws. Regarding learning, governments may assess the content of prescriptions, such as norms, practices, and beliefs, and adapt them to the domestic context. To mitigate uncertainty, policymakers tend to follow best practices. Although research often focuses on learning between countries (e.g., Kahneman, 2003), learning mechanisms can also be observed between IFIs and nation-states as countries can use external recommendations as blueprints to develop their own policies (Obinger et al., 2012; Rose, 1991; White, 2020). Emulation, on the other hand, refers to national governments' willingness to conform to international trends and ideas to belong to a specific community. In a process White (2020) described as "follow the leader," countries imitate 
the most powerful actors. Madrid (2005), for instance, suggested that ideas for which influential actors advocate will likely be enacted, regardless of their merits. Emulation can be intentional, as in a country accepting a prescription related to a specific issue (e.g., human rights) as it stands, to retain its status and avoid repercussions. Alternatively, emulation can be automatic, in which a country blindly adopts trends without evaluating their merits, costs, or benefits (Goodman \& Jinks, 2013).

Research shows that ideas are not transmitted perfectly from the international to the national level, as domestic factors, such as socio-political context and national stakeholders, can impede the transfer of foreign prescriptions or alter their content (Orenstein, 2008; White, 2020). Research further suggests that asymmetrical power dynamics make LMICs susceptible to accepting IFIs agendas. Therefore, analysing the influence of a main international player, such as the WB, on domestic healthcare reforms should demonstrate variation in the ways in which prescriptions are adopted and translated into domestic legislation in different LMICs. Evidence of policy transfer and diffusion mechanisms across different countries is necessary to understand IFIs domestic policy influence, as it may suggest whether emulation and learning are more likely to occur in countries with specific conditions.

\subsection{The World Bank as a Champion of Healthcare Reform}

By the end of the last century, there was a universal agreement among IFIs regarding the measures necessary for LMICs to improve their economies. From what came to be referred to as the "Washington Consensus," Washington D.C.-based organisations, such as the WB, International Monetary Fund, and United States' Department of the Treasury, promoted neoliberal policies targeting less-advanced economies in marketoriented programmes focusing on "the retrenchment of the welfare dimension of the state, which is seen as an impediment to the optimal functioning of the markets" (Mladenov, 2015, p. 446). This market-based approach aimed to achieve macroeconomic stabilisation through the reduction/reallocation of public expenditure, privatisation, and liberalisation, and decrease the government's role in the economy (Hancock, 1999; Undurraga, 2015). The Washington Consensus initially set this policy agenda to ease the recovery of Latin American countries after significant economic crises in the 1980s (Williamson, 1990). Technical advice combined with foreign lending triggered a wave of structural reforms in Latin America, such as social reforms (e.g., pensions and healthcare), economic reforms (e.g., liberalisation of financial and commercial markets), and tax reforms (Almeida, 2002; Haggard \& Kaufman, 2008; Homedes \& Ugalde, 2005; Mesa-Lago, 2008; Williamson, 1993). In healthcare, the neoliberal model, which centred on controlling healthcare costs, was used to intervene in the way services were financed and provided, emphasising decreased public spending and a larger role for the private sector (WB, 1993). This homogenous health agenda, supported by the most influential actors at the time, was mainly promulgated by the WB (Almeida, 2015).

The WB was the largest international health lender and reform advocate by the end of the 20th century (Homedes \& Ugalde, 2005; Tichenor \& Sridhar, 2017). Its expanding financial participation in healthcarerelated projects boosted its credibility as an important player. During its history, the WB's ideas regarding healthcare have evolved. In the 1970s, the WB mainly focused on population control, followed by projects that emphasised healthcare direct lending. Healthcare system reforms were the main focus of the 1980s and 1990s. At the beginning of the 21st century, the WB turned its attention to healthcare system enhancement (Tichenor \& Sridhar, 2017). Currently, the WB mostly advocates for universal health coverage through the investment of primary healthcare to improve access and manage health costs (Maeda et al., 2014). Aside from declaring universal health coverage to be a basic human right and increasing access to healthcare, the WB also claims there are political and economic gains in implementing universal coverage (Maeda et al., 2014; WB, 2019).

This article, however, focuses on the period in which the WB pushed for neoliberal reforms, between 1993 and 2000. Although the organisation published general prescriptions on healthcare reform still in the 1980s (e.g., WB, 1987), the WB's Investing in Health report of 1993 is considered the benchmark for LMIC healthcare reforms (Ruger, 2005; Unger et al., 2008). The report proposes a pragmatic approach based on economic principles of cost reduction and performance increase which fall under the neoliberal principles forwarded by the Washington Consensus (Almeida, 2015; WB, 1993). The report puts forth recommendations for decreasing government's role in healthcare (e.g., non-public financing and provision, decentralisation, community control, increased efficiency), reallocating public expenditure (e.g., transferring public spending to specific services and societal groups), promoting liberalisation (e.g., freedom of choice), and increasing the private sector's role (e.g., non-public financing and provision, deregulation, promoting the entry of new players to boost competition; Ruger, 2005; WB, 1993). The report claims that "the adoption of main policy recommendations by developing countries' governments would enormously improve the health status of their people...and would also help to control healthcare spending. Millions of lives and billions of dollars could be saved" (WB, 1993, p. 13).

\section{Research Design}

\subsection{The Cases}

By the end of the 1950s, all South American countries had institutionalised healthcare systems. However, 
they were restricted to specific social groups (i.e., formal employees), and approximately $75 \%$ of the population was not covered by any scheme (Giovanella \& Faria, 2015). In theory, individuals without healthcare coverage were the responsibility of health ministries; however, these were underfunded, politically weak, and institutionally inefficient (Haggard \& Kaufman, 2008; Mesa-Lago, 2008). Therefore, healthcare systems in the region were characterised by access inequalities, inadequate regulation, and insufficient financial, technical, and human resources. To address these challenges and attempt to overcome the region's debt crisis, 10 out of 12 South American countries underwent healthcare reforms at the end of the 20th century: Argentina, Bolivia, Brazil, Chile, Colombia, Ecuador, Paraguay, Peru, Uruguay, and Venezuela. This study included all reforms that began after the Investing in Health report was published, and were completed before 2000 , when the WB shifted focus from healthcare reform to healthcare system enhancement. This excluded Brazil, Chile, Ecuador, and Uruguay (Mesa-Lago, 2008). Unfortunately, Venezuela was not considered, as relevant legislation could not be retrieved.

During the examined period, the five analysed countries shared similar characteristics. Most important was the re-democratisation that all these countries, except Colombia, underwent at the time. Argentina, Bolivia, Paraguay, and Peru all experienced a return to democracy from military dictatorships, which was followed by reconstruction of democratic institutions and practices (Frantz \& Geddes, 2016). At the time of the reforms, countries were governed by centre, centre-right, or right parties (Coppedge, 1997), and were beginning to recover from the debt crisis of the 1980s, which resulted in failed public services, including those pertaining to healthcare (Alesina, 2005; Felix, 1990). Between $40 \%$ and $65 \%$ of the population lived in poverty, with Argentina being an exception. Further, foreign debt as a percentage of GNI was approximately $30 \%$ in Argentina, Colombia, and Paraguay, and $54 \%$ and $82 \%$ in Peru and Bolivia, respectively (WB, 2021), leaving these countries more susceptible to international pressure. Table 1 shows selected information on each country's internal conditions one year before reform began. For instance, as Argentinean and Colombian reform started in 1993, the data for these countries refer to 1992.

Although the WB's recommendations generally targeted LMICs, the neoliberal agenda in place at the end of the 20th century was initially developed to ease the recovery of Latin American countries facing significant economic crises (Williamson, 1990), making the five countries suitable for analysing the influence of IFIs on domestic reforms.

\subsection{Data Collection and Analysis}

The data for this research came from two main sources: the WB and domestic legislation. First, the World Development Report: Investing in Health (1993), the most influential document on healthcare reform published by the WB, was analysed (Almeida, 2015; Ruger, 2005; Unger et al., 2008). It sets key recommendations for LMICs to create "an environment that enables households to improve health, improve government spending

Table 1. Domestic conditions prior to reform, by country (reference year in parentheses).

\begin{tabular}{|c|c|c|c|c|c|}
\hline & $\begin{array}{l}\text { Argentina } \\
\text { (1992) }\end{array}$ & $\begin{array}{l}\text { Bolivia } \\
\text { (1995) }\end{array}$ & $\begin{array}{c}\text { Colombia } \\
(1992)\end{array}$ & $\begin{array}{l}\text { Paraguay } \\
\text { (1995) }\end{array}$ & $\begin{array}{c}\text { Peru } \\
(1996)\end{array}$ \\
\hline $\begin{array}{l}\text { Classification party in power, } \\
\text { executive branch } \\
\text { (Coppedge, 1997) }\end{array}$ & Centre-right & Centre-right & Centre & Right & Right \\
\hline $\begin{array}{l}\text { Classification party in power, } \\
\text { legislative branch } \\
\text { (Coppedge, 1997) }\end{array}$ & Centre-right & Centre-right & Centre & Right/Centre-left & Right \\
\hline External debt (\% GNI; WB, 2021) & 30.5 & 82.3 & 31.2 & 32 & 54.1 \\
\hline $\begin{array}{l}\text { GDP per capita growth } \\
\text { (annual \%; WB, 2021) }\end{array}$ & 6.4 & 2.5 & 2 & 4.3 & 0.9 \\
\hline $\begin{array}{l}\text { GDP per capita, PPP (constant } \\
2017 \text { international \$; WB, 2021) }\end{array}$ & 16,209 & 5,050 & 8,478 & 9,311 & 6,210 \\
\hline $\begin{array}{l}\text { Net ODA received } \\
(\% \mathrm{GNI} \text {; WB, 2021) }\end{array}$ & 0.1 & 10.4 & 6.9 & 0.4 & 0.6 \\
\hline $\begin{array}{l}\text { Population living on less than } \\
5.5 \text { US dollars/day (\% total } \\
\text { population; ECLAC, 2021) }\end{array}$ & 14.8 & 65 & 46.7 & 40.2 & 54 \\
\hline
\end{tabular}


on health, and promote diversity and competition" (WB, 1993, p. 6). The document is 329 pages long and divided into seven parts. In chapters one through six, household capacity, the roles of the government and private sector in healthcare, public health status, and clinical services are discussed as they pertain to health conditions in LMICs. Chapter seven summarises the main findings of the report and sets a policy-reform agenda for LMICs. This chapter was examined in the present study. Additionally, this study considered the legal framework of healthcare reform in the five countries (Table 2). First, the policies indicated by healthcare authorities in each country enacted during the reform period were examined. These were cited in a report organised by the South American Institute of Government in Health (ISAGS) and authored by South American health ministries. When the report did not clearly indicate the main legislation of a country's reforms, relevant literature was reviewed to identify the documents constituting the reforms. Notably, healthcare reform processes were often a combination of acts. As a result, some of the legislation encompasses more policy fields than only healthcare. This study, however, only considered measures related to healthcare, excluding any references to other fields.

To guide the analysis, a codebook based on the prescriptions set by the report was created (Table 3). These prescriptions were categorised into three themes: financing, regulation, and service provision. The analysis in the first instance was based on inductive logic using the codes created from analysing the report. In the second stage, all legislation was deductively examined against the themes. The legislation was systematically examined using content analysis (see Neuendorf \& Kumar, 2015). The approach used in this research comprised the following steps: (a) identifying the main documents based on secondary literature and those indicated by governmental bodies, (b) examining the WB's Investing in Health report to identify its main themes and prescriptions, (c) creating a codebook, (d) coding the legislation using the codebook, (e) quantitatively describing the results, and ( $f$ ) qualitatively analysing and interpreting the documents' content. Altogether, 13 documents containing 163 pages were evaluated using NVivo software. The author systematically coded the textual data.

\section{Results}

In total, 420 references to the codes were identified across 12 laws. The WB prescriptions were cited most in Argentina and Colombia, with legislation including 122 and 124 references, respectively, to the main themes. The Paraguayan legislation contained 82 references to WB recommendations. In the Bolivian and Peruvian

Table 2. Policy documents.

\begin{tabular}{|c|c|c|c|}
\hline Country & Legal act & Contents & Sources \\
\hline \multirow[t]{5}{*}{ Argentina } & Decree No. 9/1993 & $\begin{array}{l}\text { Guarantees beneficiaries the freedom of choice to } \\
\text { select healthcare providers }\end{array}$ & $\begin{array}{l}\text { Cetrángolo and } \\
\text { Devoto (2002) }\end{array}$ \\
\hline & Decree No. 576/1993 & $\begin{array}{l}\text { Regulates the Sistema de Obras Sociales (health } \\
\text { insurance) and the Sistema National del Seguro } \\
\text { de Salud (national health insurance) }\end{array}$ & ISAGS (2012) \\
\hline & Decree No. 1615/1996 & $\begin{array}{l}\text { Consolidates healthcare institutions and } \\
\text { decentralises their functions }\end{array}$ & ISAGS (2012) \\
\hline & Resolution No. $247 / 1996$ & $\begin{array}{l}\text { Creates the Médico Obligatorio (mandatory physician) } \\
\text { programme and regulates co-payments }\end{array}$ & ISAGS (2012) \\
\hline & Decree No. 53/1998 & Decentralises healthcare services & ISAGS (2012) \\
\hline \multirow[t]{2}{*}{ Bolivia } & Law No. $24303 / 96$ & $\begin{array}{l}\text { Creates a healthcare scheme targeting mothers } \\
\text { and children }\end{array}$ & $\begin{array}{l}\text { Lozano (2002); } \\
\text { PAHO (2008) }\end{array}$ \\
\hline & Decree No. 25265/98 & $\begin{array}{l}\text { Creates the Seguro Básico de Salud (basic health } \\
\text { insurance) }\end{array}$ & PAHO (2008) \\
\hline Colombia & Law No. 100/1993 & Reforms the social security system & ISAGS (2012) \\
\hline \multirow[t]{2}{*}{ Paraguay } & Law No. 1032/1996 & Creates the national health system & ISAGS (2012) \\
\hline & Law No. 19966/1998 & $\begin{array}{l}\text { Decentralises the national health system and } \\
\text { encourages community participation }\end{array}$ & Recalde (1999) \\
\hline \multirow[t]{2}{*}{ Peru } & Law No. $26790 / 1997$ & Reforms the social health insurance system & $\begin{array}{l}\text { Barboza-Tello (2009); } \\
\text { Sanabria (2001) }\end{array}$ \\
\hline & Law No. 26842/1997 & Defines the responsibilities of the healthcare system & ISAGS (2012) \\
\hline
\end{tabular}


Table 3. Simplified codebook.

\begin{tabular}{|c|c|c|}
\hline Main Theme & Main Codes & Recommendations \\
\hline \multirow[t]{2}{*}{ Financing } & Non-public financing & Encourage private and external sources to finance healthcare services \\
\hline & $\begin{array}{l}\text { Priorities, public } \\
\text { expenditure }\end{array}$ & $\begin{array}{l}\text { Reallocate public spending to basic healthcare services, provision of } \\
\text { services for vulnerable groups, and local health facilities }\end{array}$ \\
\hline \multirow[t]{5}{*}{ Regulation } & Community control & Encourage community control of healthcare services \\
\hline & Decentralisation & $\begin{array}{l}\text { Decentralise government healthcare services, offering greater autonomy } \\
\text { to local units of the system }\end{array}$ \\
\hline & Deregulation & $\begin{array}{l}\text { Abolish the domestic regulation of pre-paid schemes and decrease } \\
\text { bureaucracy }\end{array}$ \\
\hline & Efficiency, public sector & $\begin{array}{l}\text { Increase the effectiveness of the healthcare public sector through } \\
\text { payment incentives and decentralisation }\end{array}$ \\
\hline & Freedom of choice & Allow beneficiaries the freedom to choose their insurer and provider \\
\hline \multirow[t]{4}{*}{ Service Provision } & Benefits package & $\begin{array}{l}\text { Create and define a minimum set of healthcare services to be available } \\
\text { to beneficiaries }\end{array}$ \\
\hline & Coverage & Prioritise the delivery of healthcare services for vulnerable populations \\
\hline & Non-public provision & Encourage the private sector to deliver healthcare services \\
\hline & Quality & $\begin{array}{l}\text { Improve the quality of healthcare services through quality control, } \\
\text { investment in local facilities, community financing, and competition }\end{array}$ \\
\hline
\end{tabular}

Note: Complete codebook and coded documents available upon request to the author.

legislation, there were 42 and 50 citations, respectively. Regarding the number of times each prescription appeared, the predominant codes were benefits package (73), quality (65), coverage (64), and decentralisation (58). All but two prescriptions were mentioned at least once in each country's legislation. Deregulation only appeared in Argentinean and Colombian legislation, and freedom to choose insurers and providers did not appear in Bolivian and Paraguayan legislation.

Figure 1 shows the share of codes by main themes in the WB prescriptions, by country. Prescriptions related to "service provision" were referred to most frequently in the Bolivian, Peruvian, and Colombian reforms, accounting for $76 \%, 62 \%$, and $60 \%$ of the codes, respectively. This

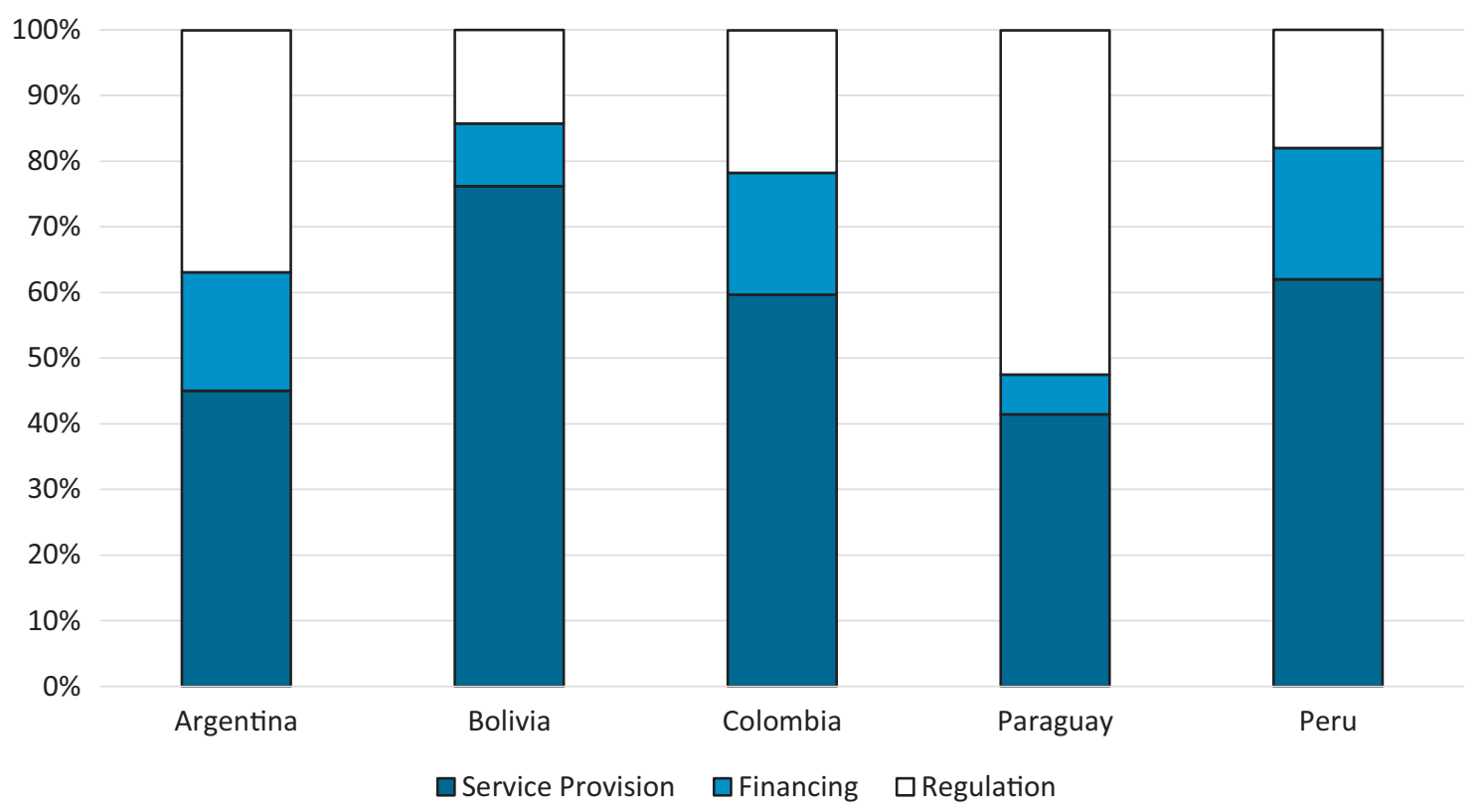

Figure 1. Share of codes by main themes of the WB prescriptions, by country. 
decreased to $45 \%$ and $41 \%$, respectively, in Argentina and Paraguay. Recommendations related to "coverage" accounted for $28 \%$ and $22 \%$ of the codes in Bolivia and Peru, respectively, and was the most frequently mentioned recommendation in Colombia. For Argentina, Paraguay, and Peru, this decreased to $5 \%, 13 \%$, and $16 \%$, respectively. "Benefits package" was the recommendation most mentioned in Bolivian legislation, with $33 \%$ of the references related to the definition of a minimum package of services. Additionally, $18 \%$ of the codes in both Argentina and Peru, and 15\% in Colombia, and 10\% in Paraguay referred to benefits package. "Quality of services" was the most cited recommendation in Argentina (20\%) and Peru (22\%). This decreased in Colombia, Paraguay, and Bolivia, to $17 \%, 8 \%$, and $2 \%$, respectively. Ultimately, In Bolivia, Paraguay, and Peru, $12 \%, 10 \%$, and $6 \%$ of the total number of citations, respectively, mentioned "non-public provision." This decreased to $5 \%$ in Colombia and 2\% in Argentina.

Prescriptions related to "regulation" were the first and second most often cited in the Colombia (52\%) and Argentina (37\%). For Colombia, Peru, and Bolivia, these represented $22 \%, 18 \%$, and $14 \%$ of all codes, respectively. In Bolivia and Argentina, $34 \%$ and $17 \%$ of the codes, respectively, referred to "decentralisation." This was the code that appeared most often for Bolivia and third most often for Argentina. For the other three countries, decentralisation comprised $5 \%$ of the total codes on average. Approximately $9 \%$ of the codes in Colombia and Paraguay addressed "community control." For the other countries, this recommendation averaged $3 \%$. Furthermore, "freedom of choice" was only referenced in the legislation of Argentina (10\%), Colombia (5\%), and Peru (10\%). Measures concerning deregulation only appeared in Argentinean (5\%) and Colombian (2\%) legislation. Finally, prescriptions associated with "financing" were cited least across all countries, representing approximately $20 \%$ in Argentina, Colombia, and Peru, and $10 \%$ and $6 \%$ in Bolivia and Paraguay, respectively.
In Peru, Argentina, and Colombia, "non-public financing" accounted for $16 \%, 15 \%$, and $14 \%$ of the codes, respectively. For the remaining countries, this recommendation accounted for approximately $3 \%$. On average, $4 \%$ of the codes referred to "priorities of public expenditure" and "public sector efficiency" in each country.

In total, the five countries adopted 57 measures associated with the WB prescriptions in three ways. First, they enacted the measure exactly as prescribed by the WB, such as implementing co-payments and pre-paid insurance schemes (replicated measure). Second, they enacted the measure, but adapted it to suit the local context (adapted measure). Third, they disregarded the WB prescription (contradicting measure).

\subsection{Prescriptions on Healthcare Systems Financing}

The WB report contained two main prescriptions on healthcare funding: reallocating public spending to specific services and societal groups and expanding non-public financing. These recommendations were addressed in 11 measures enacted across the five countries (Table 4). The report suggested public expenditure be reallocated to (a) basic clinical care, (b) services for vulnerable groups, and (c) local healthcare facilities (WB, 1993, pp. 158, 163). Bolivia, Colombia, and Peru explicitly prioritised vulnerable populations, such as children, mothers, and the poor. The Colombian legislation specifically referenced public financing for local healthcare facilities. Regarding assigning public funding for basic healthcare services, Argentina focused on clinical care, and Paraguay on primary care. Argentina and Bolivia exceeded the WB prescriptions, guaranteeing funding for public hospitals.

The second prescription for funding healthcare systems addressed mobilising financing resources other than public money to boost the healthcare budget and decrease reliance on government funds (WB, 1993, pp. 157, 159). In particular, the report referred to

Table 4. Financing measures.

\begin{tabular}{|c|c|c|c|c|c|c|}
\hline \multirow[b]{2}{*}{ Prescription } & \multirow[b]{2}{*}{ Measures } & \multicolumn{5}{|c|}{ Implemented measures by country } \\
\hline & & Argentina & Bolivia & Colombia & Paraguay & Peru \\
\hline \multirow{5}{*}{ financing } & Co-payment ${ }^{\dagger}$ & $x$ & & $\mathrm{X}$ & & $\mathrm{X}$ \\
\hline & Complementary insurance§ & $x$ & & $\mathrm{x}$ & & \\
\hline & Contributiont & $x$ & & $\mathrm{X}$ & & $\mathrm{X}$ \\
\hline & Mobilise foreign resourcest & & & & $\mathrm{X}$ & \\
\hline & Mobilise not-for-profit organisational resources§ & & $\mathrm{x}$ & & $\mathrm{X}$ & \\
\hline Public & Ensure clinical care ${ }^{\dagger}$ & $x$ & & & & \\
\hline Expenditure & Establish local health facilities ${ }^{\dagger}$ & & & $\mathrm{X}$ & & \\
\hline \multirow[t]{4}{*}{ Priorities } & Ensure primary care§ & & & & $\mathrm{X}$ & \\
\hline & Provide care for children and mothers ${ }^{\dagger}$ & & $\mathrm{X}$ & & & \\
\hline & Provide care for the poor and vulnerable groups ${ }^{\dagger}$ & & & $x$ & & $\mathrm{x}$ \\
\hline & Fund public hospitals§ & $x$ & $x$ & & & \\
\hline
\end{tabular}

Note: + replicated measure, $\S$ adapted measure, ${ }^{*}$ contradicting measure. 
co-payments, pre-paid insurance schemes, and external funds. Paraguay was the only country to implement a measure specifically noting external resources as a healthcare financing source. Argentina, Colombia, and Peru adopted co-payment and payroll contribution mechanisms. Paraguay and Bolivia encouraged the mobilisation of private resources through collaboration between public and private not-for-profit institutions. Argentina and Colombia also established complemen- tary insurance to make services available that were not included in the minimum benefits package.

\subsection{Prescriptions for Healthcare System Regulation}

Regarding regulation, the WB provided five groups of recommendations, in response to which the analysed countries developed 22 measures (Table 5). Notably, recommendations on system regulation were not as specific as

Table 5. Regulation measures.

\begin{tabular}{|c|c|c|c|c|c|c|}
\hline \multirow[b]{2}{*}{ Prescription } & \multirow[b]{2}{*}{ Measures } & \multicolumn{5}{|c|}{ Implemented measures by country } \\
\hline & & Argentina & Bolivia & Colombia & Paraguay & Peru \\
\hline \multirow{5}{*}{$\begin{array}{l}\text { Community } \\
\text { control }\end{array}$} & Administrative participation§ & $\mathrm{x}$ & $\mathrm{X}$ & $\mathrm{X}$ & $\mathrm{x}$ & $x$ \\
\hline & $\begin{array}{l}\text { Participation in developing health campaigns } \\
\text { and policies§ }\end{array}$ & & & & $\mathrm{x}$ & \\
\hline & $\begin{array}{l}\text { Participation in implementing health } \\
\text { campaigns and policies§ }\end{array}$ & & & & $\mathrm{x}$ & \\
\hline & $\begin{array}{l}\text { Create user associations to regulate providers, } \\
\text { if possible } \S\end{array}$ & & & $\mathrm{X}$ & & \\
\hline & $\begin{array}{l}\text { Give communities responsibility to evaluate } \\
\text { services§ }\end{array}$ & $\mathrm{x}$ & & $x$ & & \\
\hline \multirow[t]{6}{*}{ Decentralisation } & $\begin{array}{l}\text { Transfer budget planning to local } \\
\text { governments§ }\end{array}$ & $\mathrm{x}$ & $\mathrm{X}$ & & & \\
\hline & $\begin{array}{l}\text { Transfer the creation of organisational } \\
\text { structures to local governments§ }\end{array}$ & $\mathrm{X}$ & & & $\mathrm{X}$ & \\
\hline & $\begin{array}{l}\text { Transfer implementation of policies and } \\
\text { processes to local governments§ }\end{array}$ & $\mathrm{x}$ & & & $\mathrm{X}$ & \\
\hline & $\begin{array}{l}\text { Transfer the administration of resources } \\
\text { (financial, human, and infrastructure) to } \\
\text { local governments§ }\end{array}$ & $\mathrm{x}$ & $\mathrm{X}$ & $\mathrm{X}$ & $\mathrm{x}$ & $x$ \\
\hline & $\begin{array}{l}\text { Transfer the responsibility to establish fees to } \\
\text { local governments } \S\end{array}$ & $\mathrm{x}$ & & & $\mathrm{x}$ & \\
\hline & $\begin{array}{l}\text { Transfer control responsibilities to local } \\
\text { governments§ }\end{array}$ & $\mathrm{x}$ & $x$ & & $\mathrm{x}$ & $x$ \\
\hline \multirow[t]{3}{*}{ Deregulation } & $\begin{array}{l}\text { Abolish regulations related to freedom to } \\
\text { choose insurers§ }\end{array}$ & $\mathrm{X}$ & & $X$ & & \\
\hline & $\begin{array}{l}\text { Abolish regulations related to freedom to } \\
\text { choose providers } \S\end{array}$ & $\mathrm{x}$ & & $\mathrm{X}$ & & \\
\hline & Decrease control over pre-paid schemest & $\mathrm{x}$ & & $\mathrm{X}$ & & \\
\hline \multirow[t]{5}{*}{$\begin{array}{l}\text { Efficiency, } \\
\text { public sector }\end{array}$} & $\begin{array}{l}\text { Use technical resources (service provision) } \\
\text { more efficiently§ }\end{array}$ & $\mathrm{x}$ & $\mathrm{X}$ & $\mathrm{X}$ & $\mathrm{x}$ & $x$ \\
\hline & Use administrative resources more efficiently§ & $x$ & & $\mathrm{X}$ & $\mathrm{x}$ & \\
\hline & Use financial resources more efficiently§ & & & $\mathrm{X}$ & $\mathrm{x}$ & \\
\hline & $\begin{array}{l}\text { Increase provider productivity through } \\
\text { financial bonusest }\end{array}$ & & & $\mathrm{x}$ & & \\
\hline & $\begin{array}{l}\text { Increase provider productivity through } \\
\text { continuing education§ }\end{array}$ & & & $\mathrm{X}$ & & \\
\hline \multirow[t]{3}{*}{$\begin{array}{l}\text { Freedom } \\
\text { of choice }\end{array}$} & $\begin{array}{l}\text { Secure competition between public and } \\
\text { private sectors }{ }^{\dagger}\end{array}$ & & & $X$ & & \\
\hline & Secure freedom to choose insurers ${ }^{\dagger}$ & $\mathrm{x}$ & & $\mathrm{X}$ & & $x$ \\
\hline & Secure freedom to choose providers ${ }^{\dagger}$ & $\mathrm{x}$ & & $\mathrm{X}$ & & \\
\hline
\end{tabular}

Note: † replicated measure, $\S$ adapted measure, * contradicting measure. 
those on service provision and financing. Although the WB provided guidelines on community involvement in financing healthcare, it did not prescribe methods for how communities should regulate healthcare. As the prescriptions were not detailed, countries developed their own measures. All five countries assigned administrative responsibilities to local communities and appointed local members to managerial roles. For example, Argentina transferred all administrative powers to communities, freeing the state to focus on aspects of the system that could not be monitored by communities. Paraguayan communities were also made partially responsible for developing and implementing health campaigns and policies, and Colombia delegated the regulation of providers and service evaluation to communities. Argentinean legislation also assigned communities the responsibility of evaluating service delivery.

The WB pushed two measures to increase public sector efficiency: payment incentives and decentralisation. Colombia, however, was the only country that developed financial and continuing education programmes for health professionals. Nonetheless, reducing public-sector inefficiency was cited in all five countries' legislation. For example, all countries' legislation mentioned better use of resources, such as technical (Argentina, Bolivia, Colombia, Paraguay, and Peru), administrative (Argentina, Colombia, and Paraguay), and financial (Colombia and Paraguay). Regarding decentralisation, the WB (1993, p. 163) claimed that it was "potentially the most important force for improving efficiency and responding to local health conditions and demands." The WB did not refer to a specific prescription on which responsibilities should be decentralised; the report only mentioned that greater autonomy should be provided to local units of the system. In all the countries' legislation, six responsibilities were transferred from national to local governments. Specifically, administration of financial, human, and infrastructure resources were assigned to local governments. Further, in all countries except Colombia, local governments were assigned the responsibility of controlling healthcare. The Argentinean and Paraguayan national governments also transferred the authority to create organisational structures, implement policy and processes, and set healthcare service fees to local governments. Finally, in Argentina and Bolivia, budget planning became the responsibility of local governments.

The WB (1993) also advocated for freedom of choice and deregulation, claiming that free competition within the healthcare sector would improve quality and encourage efficiency. According to the WB, consumers should have the freedom to choose their insurers, and there should be free competition between public and private healthcare providers and between service suppliers. Through eliminating pre-existing regulations and ensuring free competition, measures allowing consumers to choose insurers (Argentina, Colombia, and Peru) and providers (Argentina and Colombia) were established. In fact, a central goal of the Colombian reform was to secure free competition between the private and public sectors. Regarding deregulation, the WB $(1993$, p. 161) encouraged governments to promote non-public schemes by removing legal barriers impeding their operation, which both Argentina and Colombia did. Argentinean legislation also dissolved rules that hindered users from choosing insurers and healthcare providers. However, neither Bolivia nor Paraguay implemented measures on freedom of choice or deregulation.

\subsection{Prescriptions on Service Provision}

Table 6 shows how the countries approached recommendations on health service delivery. As previously mentioned, the creation of a standardised minimum service package was the most-referenced prescription (73). The WB report advised that a minimum set of health services must be available to all beneficiaries. Although the report recognised that countries have different healthcare needs, and that such a package should be defined by each nation, the WB emphasised the importance of delivering essential clinical services, specifically "sick-child care, family planning, prenatal and delivery care, and treatment for tuberculosis and sexually transmitted diseases (STDs)" (p. 7). All countries' legislation provided for the minimum services defined by the WB; sick-child, prenatal, and delivery care would be available to all beneficiaries. Additionally, all legislation established more comprehensive packages than the minimum the WB recommended. For example, Argentina provided primary, secondary, tertiary, dental, and psychiatric care. The other countries guaranteed additional primary and clinical care services. Family planning measures were adopted in Bolivia, Paraguay, and Peru. Argentina, Bolivia, and Colombia guaranteed treatment for tuberculosis and STDs. Other health services not covered by the minimum benefits package, such as treatment for diseases with low incidence and high costs, were available through user fees in Argentina, Colombia, and Peru.

As previously mentioned, a main goal of the WB's Investing in Health was to reduce the size and cost of the public sector and only provide public services to vulnerable groups, namely the poor, mothers, and children:

Effective targeting of publicly subsidised clinical services to the poor, and corresponding efforts to encourage cost recovery from more affluent groups, would help stretch limited government budgets...to improve the quality and efficiency of public health services and essential clinical care, especially for mothers and children. (WB, 1993, pp. 158, 169)

The analysed legislation clearly stated which group(s) benefited from public services and spending. Contrary to the WB's recommendations, all Bolivian and Paraguayan citizens were entitled to public healthcare. The Paraguayan legislation stated that comprehensive 
Table 6. Service provision measures.

\begin{tabular}{|c|c|c|c|c|c|c|}
\hline \multirow[b]{2}{*}{ Prescription } & \multirow[b]{2}{*}{ Measures } & \multicolumn{5}{|c|}{ Implemented measures by country } \\
\hline & & Argentina & Bolivia & Colombia & Paraguay & Peru \\
\hline Benefits & Create a minimum benefit package ${ }^{\dagger}$ & $\mathrm{X}$ & $\mathrm{X}$ & $x$ & $\mathrm{X}$ & $x$ \\
\hline \multirow[t]{5}{*}{ Package } & Provide sick-child care ${ }^{\dagger}$ & $x$ & $x$ & $x$ & $x$ & $x$ \\
\hline & Provide family planning actions ${ }^{\dagger}$ & & $\mathrm{X}$ & & $\mathrm{X}$ & $x$ \\
\hline & Provide prenatal and delivery care ${ }^{\dagger}$ & $\mathrm{X}$ & $\mathrm{X}$ & $\mathrm{X}$ & $\mathrm{X}$ & $x$ \\
\hline & Provide tuberculosis and STD treatment ${ }^{\dagger}$ & $\mathrm{x}$ & $\mathrm{X}$ & $x$ & & \\
\hline & Provide other services§ & $\mathrm{x}$ & $\mathrm{x}$ & $\mathrm{x}$ & $\mathrm{x}$ & $x$ \\
\hline \multirow[t]{5}{*}{ Coverage } & Provide coverage for childrent & & $\mathrm{x}$ & & & \\
\hline & Provide coverage for mothers ${ }^{\dagger}$ & & $\mathrm{X}$ & & & \\
\hline & Provide coverage for poor population ${ }^{\dagger}$ & & & $\mathrm{X}$ & & $\mathrm{x}$ \\
\hline & Provide coverage for residents* & & $\mathrm{x}$ & & $\mathrm{X}$ & \\
\hline & Social health insurance contributors§ & $\mathrm{X}$ & & $\mathrm{X}$ & & $\mathrm{x}$ \\
\hline Non-public & Incentivise and invest in private for-profit facilities ${ }^{\dagger}$ & $\mathrm{X}$ & $\mathrm{X}$ & $\mathrm{X}$ & $\mathrm{X}$ & $\mathrm{x}$ \\
\hline Provision & $\begin{array}{l}\text { Incentivise and invest in private not-for-profit } \\
\text { facilities }{ }^{\dagger}\end{array}$ & & $x$ & $x$ & $\mathrm{x}$ & \\
\hline \multirow[t]{11}{*}{ Quality } & Establish standards for service provision§ & $x$ & & $x$ & $\mathrm{x}$ & $x$ \\
\hline & Provide services with similar quality standards§ & $\mathrm{X}$ & $\mathrm{x}$ & $\mathrm{X}$ & $\mathrm{X}$ & $x$ \\
\hline & Establish government control of service provision ${ }^{\dagger}$ & & $x$ & $\mathrm{X}$ & $\mathrm{X}$ & $x$ \\
\hline & $\begin{array}{l}\text { Establish government evaluation of service } \\
\text { provision }{ }^{\dagger}\end{array}$ & & $\mathrm{x}$ & $x$ & $\mathrm{x}$ & \\
\hline & Establish provider control of service provision ${ }^{\dagger}$ & & & & & $x$ \\
\hline & Establish provider evaluation of service provision ${ }^{\dagger}$ & & & & & $x$ \\
\hline & Establish beneficiary control of service provision ${ }^{\dagger}$ & $\mathrm{X}$ & & & & \\
\hline & $\begin{array}{l}\text { Establish beneficiary evaluation of service } \\
\text { provision }{ }^{+}\end{array}$ & $\mathrm{x}$ & & $\mathrm{X}$ & & \\
\hline & Invest in local facilitiest & & & $\mathrm{X}$ & & \\
\hline & Establish community financing ${ }^{\dagger}$ & $\mathrm{X}$ & & $\mathrm{X}$ & & $\mathrm{x}$ \\
\hline & Ensure freedom to select insurerst & $\mathrm{X}$ & & $\mathrm{X}$ & & $\mathrm{x}$ \\
\hline
\end{tabular}

Note: $\dagger$ replicated measure, $\S$ adapted measure, ${ }^{*}$ contradicting measure.

services would be available to the entire population, without political, economic, or social discrimination (Paraguay National Government, 1998). However, the country also implemented additional prevention and primary care programmes targeting vulnerable groups. The first healthcare reform legislation enacted in Bolivia focused only on mothers and children, creating specific health programmes for them (Bolivia National Government, 1996). However, subsequent legislation expanded coverage to all residents (Bolivia National Government, 1998). Comparable to Paraguay, the legislation also acknowledged specific health needs of vulnerable groups, children, women, rural communities, and the poor.

Colombia and Peru adopted similar approaches to healthcare coverage, matching the WB prescriptions. These countries established two parallel systems, one for groups that could afford social health insurance through payroll contributions and another for the poorest segments of society. The Peruvian reform legislation stated that public funding should fully or partially pay for healthcare for underprivileged groups not cov- ered by other schemes. The healthcare system segmentation in Colombia was even more institutionalised, creating "contributory" and "subsidised" systems. The former comprised all formal employees, public servants, pensioners, retired people, and those who could afford insurance, while the latter targeted the poorest and most vulnerable segments of society. The contribution rate of the subsidised system was based on socioeconomic factors. Although the legislation claimed there would be no difference in terms of service provision between the systems, subsidised beneficiaries were not able to select health providers or insurers. Finally, the Argentinean reform only addressed pre-paid health insurance schemes, without providing specific guidance for those who could not afford them.

Further, the WB (1993, p 157) recommended outsourcing healthcare provision, encouraging the private sector to deliver clinical services, "including those that are publicly financed." The report, however, did not distinguish between for-profit and not-for-profit organisations. All countries incentivised services provided in private for-profit facilities. For example, in 1998, Paraguay 
established a public-private partnership as a mechanism to increase health coverage. Bolivia, Colombia, and Paraguay also explicitly encouraged the delivery of services by not-for-profit facilities, such as churches, charities, and associations. Finally, the WB (1993) stated that countries should improve the service quality through quality control, investment in local facilities, community financing (user fees and pre-paid insurance), and freedom to choose insurers. The WB did not designate which actors should be responsible for quality control. In Bolivia, Colombia, and Paraguay, the state was responsible for regulating and assessing service quality, although in Paraguay, service evaluation was shared between the state and beneficiaries. Argentina transferred both obligations to beneficiaries. In Peru, providers were responsible for controlling and evaluating services, but shared control with the state. As previously mentioned, Colombia was the only country that explicitly allocated public funding to local facilities. Community financing and freedom to choose insurers were guaranteed in Argentina, Colombia, and Peru. All the countries went beyond WB prescriptions by guaranteeing services with similar quality standards would be provided to all citizens, and all countries but Bolivia created service provision standards.

\section{Discussion and Conclusion}

Recent literature on the comparative welfare state emphasises IFIs' influence on domestic policymaking. These institutions provide social policy prescriptions to national governments, setting agenda for reform. For LMICs, where power asymmetries and reliance on foreign resources can be considerable, the impact of IFIs can be even more substantial. The mechanisms through which international knowledge is transferred from global actors to nation-states has also been examined. This research focused on emulation and learning processes, in which governments conform to international knowledge, copying trends in the case of the former, and adapting foreign practices to suit the national context after assessing their merit, in the case of the latter. To indicate whether and how prescriptions formulated by IFIs are adopted in the content of domestic healthcare policy, a content analysis was conducted of key South American healthcare reform policy documents vis-à-vis recommendations provided by the WB.

This study's first main finding is that almost all WB prescriptions were addressed across the five countries. Argentina and Colombia developed measures that addressed all the recommendations, Peru cited all recommendations except deregulation, and Bolivia and Paraguay mentioned nine recommendations, leaving aside deregulation and freedom of choice. These results show that WB prescriptions had a meaningful impact on healthcare reform content in all five countries, as the 11 prescriptions resulted in 57 measures. Figure 2 shows the measures each country adopted. Black denotes the share of prescriptions adopted exactly as recommended (replicated measures). Grey displays the share of measures that were related to the recommendations but were adapted to fit local context (adapted measures). White highlights the proportion of the measures that did not align with WB instructions (contradictory measures).

Of the WB prescriptions, 31 were accepted exactly as recommended (replicated measures): 19 related to service provision, seven to financing, and five to regulation. In absolute terms, Colombia adopted most WB prescriptions exactly as recommended (23; 60.5\% of all measures). In Peru, 65\% (15) of the measures were accepted exactly as they were prescribed. Argentina and Bolivia enacted 16 (47\%) and 13 (56\%)

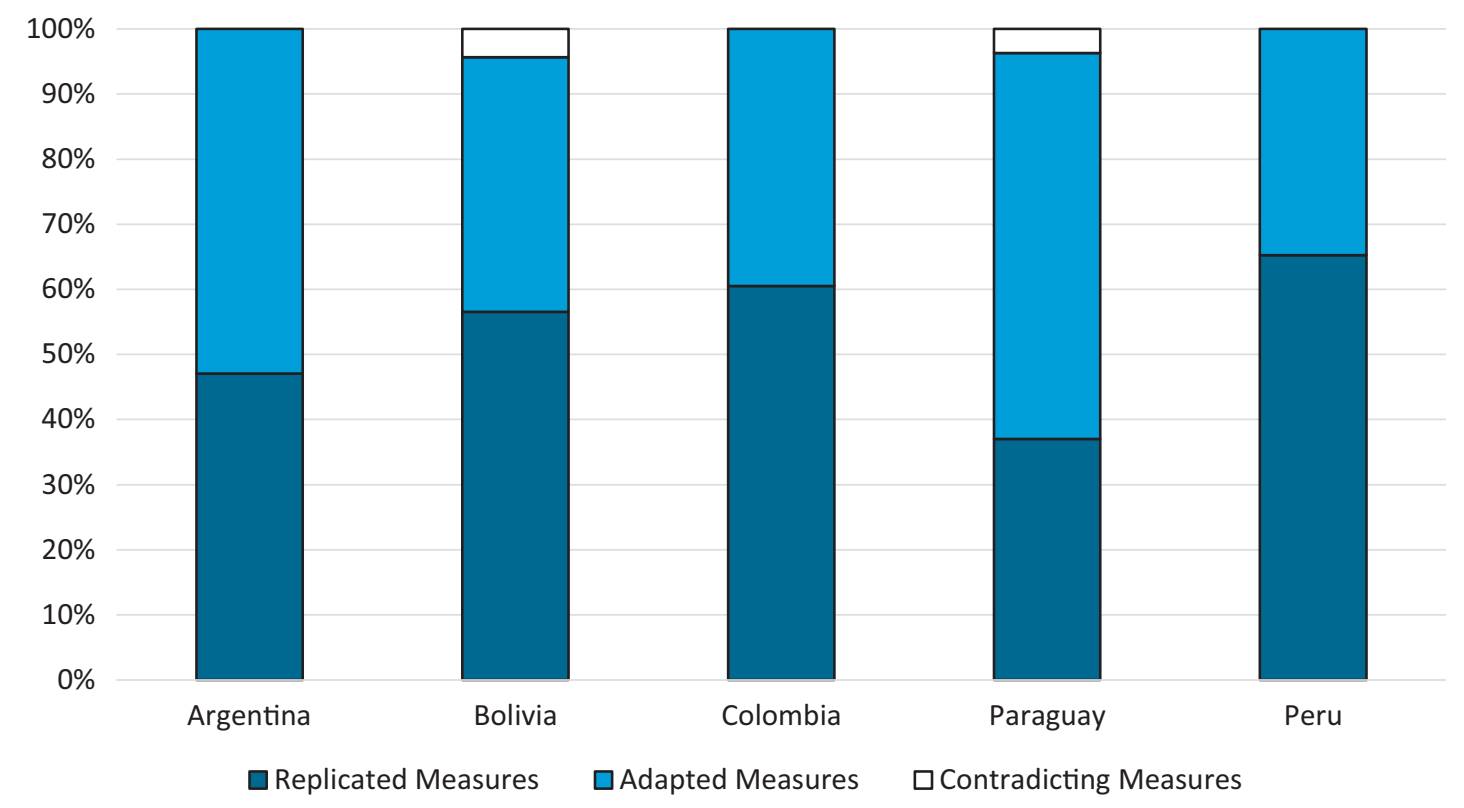

Figure 2. Measures adopted by country. 
recommendations as prescribed, respectively. Paraguay implemented $10(37 \%)$ prescriptions exactly as provided. Prescriptions on service provision were the most accepted as they were stipulated (19), representing $61 \%$ of all accepted measures. Colombia and Peru adopted the most prescriptions on service provision (13) exactly as stipulated. Measures on financing were disregarded most often. Of the seven specific recommendations, Bolivia and Paraguay adopted only one exactly as recommended. In contrast, Colombia adopted most recommendations on financing exactly as prescribed. Of the five WB prescriptions on regulation, Paraguay and Bolivia did not adopt any exactly as proposed.

In what can be described as a learning process, countries also adapted the WB recommendations by slightly modifying or expanding their content according to the local context. In total, 25 measures were adapted. Of the five countries, Argentina and Paraguay most often adapted WB instructions: 18 (53\%) and 16 (59\%), respectively. This decreased for Bolivia and Colombia (almost 40\%) and Peru (35\%). The prescriptions on regulation were most often adapted, accounting for 17 measures across all countries. This seems logical, as prescriptions on regulation were not as specific as those on service delivery and financing. Finally, the analysis identified one contradicting measure. Although this may seem insignificant considering the number of replicated or adapted propositions, Bolivia and Paraguay disregarded the WB's chief recommendation by granting free universal healthcare coverage to all residents, rather than having public services target the most vulnerable segments of society. This was in direct contravention of the report's main goal of reducing the size and cost of the public sector.

Based on the present results, the Colombian and Peruvian reforms followed the recommendations most closely; over $60 \%$ of their measures followed the prescriptions exactly as recommended. This was closely followed by the Bolivian reform, with $56.6 \%$ of the measures conforming to the recommendations, although the targeting prescription was ignored. On the other hand, Argentina and Paraguay adapted the prescriptions most often. In particular, Paraguay modified or contravened the prescriptions in $64 \%$ of its measures. In Argentina, $53 \%$ of its measures were adapted or expanded to accommodate country specificities. The countries that followed the prescriptions more loosely showed similarities. At the time of their reforms, Argentina and Paraguay had the highest GDP growth and GDP per capita and received the least foreign aid/loans. Additionally, together with Colombia, they had the least foreign debt. In a region with high poverty levels, Argentina and Paraguay also had the lowest percentage of people living on less than $\$ 5.5 /$ day. However, the share of people living on less than $\$ 5.5 /$ day differed greatly between Argentina (14.8\%) and Paraguay (40\%). The countries that most closely emulated the WB prescriptions, Bolivia, Colombia, and Peru, also shared commonalities, particularly Bolivia and Peru. They had the least developed economies, with low GDP per capita, more than half of the population living in poverty, and an extremely high rate of foreign debt. Although the domestic circumstances of Colombia paralleled those of the countries that adapted the most measures (Argentina and Paraguay), it was receiving the second highest amount of foreign aid/loans at the time, which may have been a factor in why its reforms followed the WB prescriptions so closely.

The characteristics of countries that were more prone to replicate prescriptions point to a negative correlation between economic development and reliance on external resources and the willingness to adhere to prescriptions exactly as they were recommended, without adapting them to the domestic context. Notably, this study does not establish causal explanations, but identifies possible relationships that should be further investigated. In line with the literature, the content analysis provides robust evidence of alignment between LMIC domestic policy and WB recommendations. Further, it empirically shows that foreign ideas are not uniformly adopted among countries, and that ideas advocated for by influential actors are likely to be enacted, regardless of the content's merits, especially by more economically vulnerable countries. In the context of Latin American healthcare reforms during the 1990s, the timing and content of the legislation suggest that the WB indeed had an impact.

However, the present findings point to new research avenues. Thus, future studies must examine whether ratified measures were actually implemented. This is needed to assess the practical implications of foreign prescriptions and analyse the power dynamics between IFIs and national policymakers. Therefore, the results of this study raise further questions. Do LMICs implement foreign healthcare system prescriptions? How do IFIs' recommendations impact health outcomes in LMICs? If the prescriptions are legally ratified but not implemented, do LMICs enact IFIs recommendations only as a formality to not jeopardise their future relationships with IFIs? Alternatively, is the non-implementation of measures owing to a lack of institutional capability? As the implementation of foreign agendas could have major implications for healthcare access, costs, and outcomes, and, therefore, political and electoral ramifications, an analysis of how national stakeholders receive and interact with IFIs healthcare prescriptions is also necessary to elucidate the acceptance of international recommendations and whether healthcare is an arena of social dispute. Further, different methods, such as in-depth interviews and detailed case studies, are needed to confirm this study's main findings.

\section{Acknowledgments}

I thank Achim Schmid and Salo de Carvalho for their comments on early versions of this research, and Antonio Basilicata for editorial support. This work was supported 
by the Deutsche Forschungsgemeinschaft (DFG, German Research Fundation) - project number 374666841-SFB 1342.

\section{Conflict of Interests}

The author declares no conflict of interests.

\section{References}

Alesina, R. (2005). Institutional reforms: The case of Colombia (1st ed.). MIT Press.

Almeida, C. (2002). Reforma de sistemas de servicios de salud y equidad en América Latina y el Caribe: Algunas lecciones de los años 80 y 90 [Health systems reform and equity in Latin America and the Caribbean: Lessons from the 1980s and 1990s]. Cadernos de Saúde Pública, 18(4), 905-925.

Almeida, C. (2015). O Banco Mundial e as reformas contemporâneas do setor saúde [The World Bank and the contemporary reforms of the health sector]. In J. Pereira \& M. Pronko (Eds.), Demolição de direitos: Um exame das políticas do Banco Mundial para a educação e saúde [Demolition of rights: A review of World Bank's policies for education and health] (pp. 183-122). Fio Cruz.

Barboza-Tello, M. (2009). El aseguramiento universal en el Perú: La reforma del financiamiento de la salud en perspectiva de derechos [Universal assurance in Peru: Health financing reform in rights perspectives]. Revista Peruana de Medicina Experimental y Salud Pública, 26(2), 243-247.

Bolivia National Government. (1996). Decreto Supremo No.24303, 24 de mayo de 1996 [Decree No.24303, May 24, 1996].

Bolivia National Government. (1998). Decreto Supremo No.25265, 31 de diciembre de 1998 [Decree No.25265, December 31, 1998].

Cetrángolo, O., \& Devoto, F. (2002). Organización de la salud en Argentina y equidad: Una reflexión sobre las reformas de los años noventa e impacto de la crisis actual [Health organisation and equality in Argentina: A reflection on the 1990s reforms and the impact of the current crisis]. In Proceedings of the regional consultation on policy tools: Equity in population health (pp. 1-31). https://repositorio.cepal. org/handle/11362/28457

Clements, B., Gupta, S., \& Nozaki, M. (2013). What happens to social spending in IMF-supported programmes? Applied Economics, 45(8), 4022-4033.

Coppedge, M. (1997). A classification of Latin American political parties (Working Paper no. 244). Kellogg Institute. https://kellogg.nd.edu/documents/1539

Deacon, B. (2007). Global social policy \& governance (1st ed.). SAGE.

ECLAC. (2021). CEPALSTAT-Databases and statistical publications [Data set]. Economic Commission for Latin America and the Caribbean. https://
estadisticas.cepal.org/cepalstat/Portada.html? idioma=english

Felix, D. (1990). Latin America's debt crisis. World Policy Journal, 7(4), 733-771.

Frantz, E., \& Geddes, B. (2016). The legacy of dictatorship for democratic parties in Latin America. Journal of Politics in Latin America, 8(1), 3-32.

Giovanella, L., \& Faria, M. (2015). Health policy reform in South America. In E. Kuhlmann, R. Blank, I. Bourgeault, \& C. Wendt (Eds.), The Palgrave international handbook of healthcare policy and governance (pp. 204-221). Palgrave Macmillan.

Goodman, R., \& Jinks, D. (2013). Socializing states: Promoting human rights through international law (1st ed.). Oxford University Press.

Haggard, S., \& Kaufman, R. (2008). Development, democracy, and welfare states: Latin America, East Asia and Eastern Europe. Princeton University Press.

Hancock, L. (1999). Women, public policy, and the state. Palgrave Macmillan.

Homedes, N., \& Ugalde, A. (2005). Why neoliberal health reforms have failed in Latin America. Health Policy, 71(1), 83-96.

Kaasch, A. (2013). Contesting contestation: Global social policy prescriptions on pensions and health systems. Global Social Policy, 13(1), 45-65.

Kahneman, D. (2003). Maps of bounded rationality: Psychology for behavioural economics. American Economic Review, 93(5), 1449-1475.

Leibfried, S., \& Pierson, P. (1995). European social policy: Between fragmentation and integration. The Brookings Institution.

Lozano, G. (2002). Historia de la salud publica en Bolivia: De las juntas de sanidad a los directorios locales de salud [History of the public health in Bolivia: Of the health boards to the local health directories] (1st ed.). PAHO.

Madrid, R. (2005). Ideas, economic pressures, and pension privatisation. Latin American Politics and Society, 47(2), 23-50.

Maeda, A., Araujo, E., Cashin, C., Harris, J., Ikegami, N., \& Reich, M. (2014). Universal health coverage for inclusive and sustainable development: A synthesis of 11 country case studies. World Bank.

Mesa-Lago, C. (2008). Reassembling social security: A survey of pensions and healthcare reforms in Latin America (1st ed.). Oxford University Press.

Mladenov, T. (2015). Neoliberalism, postsocialism, disability. Disability \& Society, 30(3), 445-459.

Neuendorf, K., \& Kumar, A. (2015). Content analysis. In G. Mazzoleni (Ed.), The international encyclopaedia of political communication (pp. 221-230). Wiley.

Obinger, H., Schmitt, C., \& Starke, P. (2012). Policy diffusion and policy transfer in comparative welfare state research. Social Policy \& Administration, 47(1), 111-129.

Orenstein, M. (2008). Privatizing pensions: The transnational campaign for social security reform (1st ed.). 
Princeton University Press.

PAHO. (2008). Perfil del sistema de salud de Bolivia [Bolivia health system profile]. OPS.

Recalde, F. (1999). Reforma sanitaria: Política de estado en salud [Health reform: State health policy] (1st ed.). CLACSO.

Rose, R. (1991). What is lesson-drawing? Journal of Public Policy, 11(1), 3-30.

Ruger, J. (2005). The changing role of the World Bank in global health. American Journal of Public Health, 95(1), 60-70.

Sanabria, H. (2001). El proceso de la reforma en Perú [The reform process in Peru]. Revista de Salud Pública, 3(1), 116-129.

Simmons, B., Dobbin, F., \& Garrett, G. (2008). The global diffusion of markets and democracy (1st ed.). Cambridge University Press.

South American Institute of Government in Health. (2012). Health systems in South America: Challenges to the universality, integrality and equity.

Stallings, B. (1992). International influence on economic policy, debt stabilization, and structural reform. In S. Haggard \& R. Kaufman (Eds.), The politics of economic adjustment (pp. 41-89). Princeton University Press.

Tichenor, M., \& Sridhar, D. (2017). Universal health coverage, health systems strengthening, and the World Bank. BMJ, 358, 1-5.

Undurraga, T. (2015). Neoliberalism in Argentina and Chile: Common antecedents, divergent paths.
Revista de Sociologia e Política, 23(55), 11-34.

Unger, J., de Paepe, P., Canturias, G., \& Herrera, O. (2008). Chile's neoliberal health reform: An assessment and a critique. PLoS Medicine, 5(4), 542-547.

White, A. (2020). Do international organizations influence domestic policy outcomes in OECD countries? In R. Nieuwenhuis \& W. Van Lancker (Eds.), The Palgrave handbook of family policy (pp. 69-86). Palgrave Macmillan.

Williamson, J. (1990). Latin American adjustment: How much has happened? Institute for International Economics.

Williamson, J. (1993). Democracy and the Washington consensus. World Development, 21(8), 1329-1336.

Wireko, I., \& Béland, D. (2017). Transnational actors and health care reform: Why international organizations initially opposed, and later supported, social health insurance in Ghana. International Journal of Social Welfare, 26(4), 405-415.

World Bank. (1987). Financing health services in developing countries: An agenda for reform.

World Bank. (1993). World development report: Investing in health.

World Bank. (2019). High-performance health financing for universal health coverage: Driving sustainable, inclusive growth in the 21st century.

World Bank. (2021). World Bank open data [Data set]. https://data.worldbank.org

\section{About the Author}

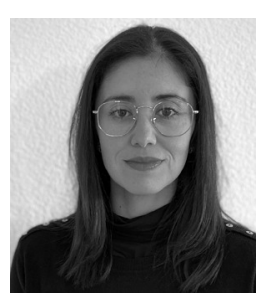

Gabriela de Carvalho is a doctoral researcher within the Collaborative Research Centre 1342, project A04 (Global Developments in Health Care Systems and Long-Term Care as a New Social Risk) at SOCIUM Research Centre on Inequality and Social Policy, University of Bremen, Germany. Her current research focuses on comparative healthcare systems and the role of global actors in the Global South. 